\section{THE ROLE OF MOTIVATION IN SECOND LANGUAGE ACQUISITION}

\author{
Rafika Nurhidayah \\ English Study Program, Sekolah Tinggi Bahasa Asing Pontianak \\ rafikanurhidayah40@gmail.com
}

Motivation,

Second

Language

Acquisition

\begin{abstract}
This paper aims to explore the role of motivation in second language acquisition. Motivation is one of the most important factors for learning a second language proficiently. Motivation is unavoidable linked with language achievement in the sense that it cannot happen without motivation. In short, motivation is used as a concept for explaining the success or failure of a language learner. There are many advantages for knowing other languages but they are not absolutely necessary, and as a consequence, motivation can play an important role in learning second language. And there are many factors that can affect this motivation.
\end{abstract}

Keywords: Motivation, second language acquisition

\title{
INTRODUCTION
}

Motivation is a kind of desire for learning. To teach a second language in a learning setting, the learners should have a desire to learn the language first. There are a numbers of factors that influence second language learning. According to Dornyei (as cited in Kaboody, 2013) stated that motivation provides the primary impetus to initiate learning the second language and later the driving force to sustain the long and often tedious learning process. Moreover, all the other factors involved in second language (L2) acquisition suppose motivation to some level. By giving sufficient motivation, it is hope that even individuals with minimal abilities can achieve long-term goals and a suitable curriculum along with good teaching will be sufficient to ensure student achievement. In addition, high motivation can cover up for significant deficiencies in both language skills and learning conditions. This is also supported by Gass and Selinker (2008) stated that a learner who is vigilant about instituting many encounters to gain comprehensible input is more likely to be successful in second language learning environments. A learner who expends the effort for memorization (even if unconsciously) is more likely to succeed in either foreign or second language environments.

SPECTRAL Jurnal Ilmiah STBA Vol.6 No.2 Juni 2020 ISSN 0216-3381 
Motivation,

Second

Language

Acquisition
Motivation plays a significant role in the rate and success of second and foreign language learning in general and in classroom language learning in particular (Kaboody, 2013). Apart from the role that intellectual capacity and language aptitude play in a second or foreign language learning, motivation is a major factor in the successful study of language acquisition. It is considered goal directed and defined as the combination of effort plus desire to achieve the goal of learning the language plus favorable attitudes toward learning the language ( $\mathrm{Xu}$ as cited in Anjomshoa and Sadighi, 2015). Furthermore, Gardner (as cited in Ghamdi, 2014) views motivation as an abstract and complex concept that is used to describe human behaviour. With a large number of definitions, it continues to highlight how complex motivation is, especially as a factor variable for L2 learners due to the dependence on different situations and conditions. For example, some students in L2 are less motivated to communicate with the target language community, whereas the opposite is proper for other students.

This is a conceptual-based paper and presented to answer the basic questions regarding the explanation of motivation such as the definition, models of motivation and types of motivation which considered affect the second language achievement.

\section{DISCUSSION}

\section{Definition of Motivation}

Motivation is considered as a major part of achieving any goal. This is an important factor that has a positive influence in every educational learning process especially in second language learning. Salvin (as cited in Rehman et all., 2014) defined motivation as an internal process that activates, guides and maintains behavior over time. Motivation is not static, it changes depending on the context and it changes over time (Gass and Selinker, 2008). Reece \& Walker (as cited in Gomleksiz, 2001), express that motivation is a key factor in the second language learning process. They emphasized that underprivileged students who are highly motivated can achieve greater success than smarter students who are not well motivated. Sometimes students come with high motivation and the teacher's job is to maintain and maximize students' motivation.

Ellis (as cited in Mahadi and Jafari, 2012) considers motivation as the attempt which learners make for learning a second language because of their need or desire to 
learn it. Gardner (as cited in Zareian and Jodaei, 2015) considers effort and desire as the prerequisites to call an individual a motivated person. He proposes that in order to understand why learners are motivated, it is important to understand what the learner wants to achieve or the goals to learn a language. Within current L2 motivation research, the tendency is to define motivation, as a cumulative force of motives that is on a continuum from zero to strong (Dornyei, 2005). Meanwhile, Liuoliene and Metiuniene (2006) stated that motivation is described as goal-directed; the learners' immediate goal is to learn the language.

\section{Models of Motivation}

\subsection{Gardner's Model}

According to Root (1999), Gardner was one of the pioneering researcher in second language acquisition (SLA) to focus on motivation. He chose to define motivation by specifying four aspects of motivation such as, a goal, effortful behavior to reach the goal, a desire to attain the goal and positive attitudes toward the goal. Goals are stimuli that give rise to motivation. A goal, nevertheless, is not necessarily a measurable component of motivation. Gardner focused on classifying reasons for second language studies, which he later identified as orientation. He found two main orientations through his research which are integrative and instrumental. In applying this research model, attention is sometimes directed at an individual scale, for example attitudes towards learning situations, intensity of motivation, etc. and sometimes the focus is on a mix of components, eg scores on integrativeness, attitude. for learning situations, and / or motivation to obtain a total score of integrative motivation (Zareian and Jodaei, 2015).

\subsection{Dornyei's Model}

According to Root (1999) stated that contrary to Gardner's focus on integrativeness, Dornyei asserted that in a foreign language setting instrumental orientation would have a greater influence on language learners. Dornyei's (as cited in Bankier, 2012) divides and inspects the learning process in three stages. The first stage to generate initial motivation. This involves how to get students excited about what they are going to learn. The second stage is maintaining and protecting motivation. The
Motivation,

Second

Language

Acquisition

098

\section{$+$}


Motivation,

Second

Language

Acquisition

099

motivation, generated in the first place, must be sustained or it will fail to get out and the goal will not be achieved. The third stage is positive self-reflection. As students complete several assignments on the way to their goal, they should ponder positively about their experiences and themselves. This way, they would most likely continue without giving up.

\section{Types of Motivation}

According to Bernard (2010), several theories and categorizations contribute to an understanding of academic motivation generally and second-language motivation specifically. These include the theory of integrative motivation introduced during the social-psychological period, as well as self-determination theory, its extensions, and the general categorizations of intrinsic and extrinsic motivation developed during the cognitive-situated period.

\subsection{Instrumental and Integrative Model}

Second language learners are interested in learning native speakers of the language and understanding the main purpose of how to live in the target language. The motivation of the learners determines how ready and eager they are to get more information and to increase their ability to understand, write, and speak the second language (Engin, 2009). In the field of language learning, a typical model is the division between integrative and instrumental motivation. (Gardner \& Lambert as cited in Chalak and Kassaian, 2010). If a person learns a language primarily for a purpose like getting a job or fulfilling an academic requirement, she or he is affected by instrumental motivation. In other words, instrumental motivation refers to the motivation to acquire language as a means to an end such as promoting a career or job or reading technical texts whereas integrative motivation is concerned with the desire to be accepted by other communities. This statement is also supported by Loewen and Reinders (as cited in 
Ghamdi, 2014) explained that instrumental motivation refers to a need of fulfilment towards some objective or the motivation which derives from the perception of the tangible benefits that might result from learning a second language. Instrumental motivation includes a group of factors that associate with motivation arising from external goals, such as passing exams, financial rewards, good position or to accomplish a school requirement (Williams and Burden, 1997).

Integrative motivation has frequently been cited and considered strongly related to second language learning achievement (Hedge; Lightbown and Spada; Lins; Loewen and Reinders as cited in Ghamdi, 2014). According to Zareian and Jodaei (2015) defines integrative motivation as the main focus of many motivational researches in SLA. This indicates the increasing attention to the concept of integrative motivation. Integrative motivation occurs when learners tries to or has a desire to integrate themselves with the culture of the second language group. It characterizes the students who study an second language because of their interest in the values and cultural issues of the target community. Integrative motivated learners want to learn the target language thus they can preferable understand and get to know the people who speak the language and mess up in their culture. Integrative motivation refers to an openness to identify at least in part with another language community (Gardner and Masgoret as cited in Rehman et all., 2014).

Dornyei (2005) stated that integrative motivation in a broad term, concerns a positive interpersonal or affective disposition toward the second language group and the desire to interact with and even become similar to valued members of that community. This implies directness and respect for other cultural societies, their values, identities and way of life. Dornyei's motivational model was categorized into language level, learner
Motivation, Second Language Acquisition 
Motivation,

Second

Language

Acquisition

101

level, and learning situation level. The language level refers to aspects of the L2, including the culture, community, and the values and benefits associated with it. The individual extent consists of the learner's characteristics that language learners present to the

classroom. However, the learning situation involves various factors including the classroom environment, teacher, learning context, teaching methods, classmates, and teacher personality (Kaboody, 2013). Meanwhile, Horwitz (as cited in Engin, 2009) stated that integrative motivation begins with a personal effort and continues on with a desire to know the target language's native speakers. The purpose of student learning and activities is to learn something new.

\subsection{Intrinsic and Extrinsic Model}

There is also another concept in the field of motivation introduced by Ryan \& Deci (as cited in Mahadi and Jafari, 2012) as Self-Determination Theory. They said that Self-Determination Theory categorizes and tells apart diverse types of motivation in accordance with the different rationales, causes, or targets which strengthen a deed or an achievement. In line with this theory, the most basic difference is between intrinsic motivation and extrinsic motivation. According to Bernard (2010) stated that intrinsic motivation is then broken into three separate parts: intrinsic motivation for knowledge (doing the activity for the intrinsic pleasure of exploring ideas and knowing new things), for accomplishment (the pleasure related with mastering a task or achieving a goal), and for stimulation (feelings such as pleasure and excitement). This is also supported by Noels et.al. (2000) stated that intrinsic motivation as a sub-scale of the self-determination theory, is of three kinds: a) intrinsic motivation knowledge (i.e. the pleasure of knowing new things), intrinsic motivation accomplishment (the pleasure of accomplishing goals), and intrinsic motivation stimulation (the pleasure in doing the task). 
Differ from the intrinsic motivation, extrinsic motivation lies along a continuum from non-self-determination to self-determination. In other words, Motivation in selfdetermination theory is classified into three categories on a continuum, from unwillingness, to passive compliance, to active personal commitment (Zareian and Jodaei, 2015). Extrinsic motivation refers to pressure or rewards from the social environment for language learning. Extrinsically motivated students aim to gain better career opportunities, teacher praise or recognition or even to prove that someone is a good learner.

Even so, the characteristic of external motivation is that it implies some kind of external pressure which once removed can result in language learners leaving L2 learning (Noels, Clement, \& Pelletier, 2001). On the other hand, extrinsic motivation is motivation to do a work or an activity as a means or way to achieve a target. Those who are extrinsically motivated undertake and commit adultery because they think their contribution will lead to enviable outcomes such as respect, teacher admiration, or avoidance (prevention) of punishment (Pintrich \& Schunk, 1996).

\section{CONCLUSION}

The success in second language acquisition depends on many factors. Motivation is one of the factor among the most important ones. This paper concentrated on two main motivational orientations of language learners. First, Gardner's framework was the beginning of language research in that area. Second, Dornyei specifically devised a model of motivation for a foreign language setting. Those framework called integrative and instrumental motivation. Furthermore, this paper also presents about intrinsic and extrinsic motivation that can help the students to be aware of the importance of acquiring a foreign language. This awareness can creates a desire for the learners to learn one or more foreign languages.
Motivation,

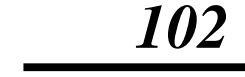


Motivation,

Second

Language

Acquisition

\section{SUGGESTION}

As has been shown in this study, motivation plays an important role as the factor in achieving L2. It cannot be denied that motivation is the basic thing in the successful

103 mastery of a second language. To specify the results, more studies are necessary to be conducted. Apart from that, this study can be more useful if it is done with a large number of English for Foreign Language (EFL) students as the participants to explore their motivation better.

\section{REFERENCES}

Ajomshoa, L. and Sadighi, F. (2015). The Importance of Motivation in Second Language Acquisition. International Journal on Studies in English Language and Literature (IJSELL), 3(2), 126-137.

Bankier, J., \& Wright, A. (2012). Applying Dörnyei's motivational strategies. In A. Stewart \& N. Sonda (Eds.), JALT2011 Conference Proceedings. Tokyo: JALT.

Bernard, J. (2010). Motivation in Foreign Language Learning: The Relationship between Classroom Activities, Motivation, and Outcomes in a University LanguageLearning Environment. Carnegie Mellon University.

Chalak, A. \& Kassaian, Z. (2010). Motivation and Attitudes of Iranian Undergraduate EFL Students towards Learning English. Journal of Language Studies. 10(2). ISSN: $1675-8021$.

Dornyei, Z.(1998). Motivation in Second and Foreign Language Learning. Journals Cambridge, 31, 117-135. doi:10.1017/S026144480001315X

Dornyei, Z. (2005). The Psychology of the Language Learner: Individual Differences in Second Language Acquisition. Mahwah, New Jersey: Lawrence Erlbaum Associates, Inc.

Engin, A. O. (2009). Second Language Learning Success And Motivation, Social Behavior And Personality, 37, 1035-1042. DOI 10.2224/Sbp.2009.37.8.1035

Gass, S., M. \& Selinker, L. (2008). Second Language Acquisition: An Introductory Course. New York: Taylor and Francis Group.

Ghamdi, A., M. (2014). The Role of Motivation as A Single Factor in Second Language Learning, ARECLS, 1-14.

Gomleksiz, M. N. (2001). The Effects of Age and Motivation Factors on Second Language Acquisition. Firat University Journal of Social Science, 2, 217-224.

Kaboody, M. A. (2013). Second Language Motivation: The Role of Teachers in Learners' Motivation. Journal of Academic and Applied Studies, 4, 45-54.

Liuoliene, A. \& Metiuniene, R. (2006). Second Language Learning Motivation. Mykolas Romeris University.

Mahadi, T. S. T., \& Jafari, S. M. (2012). Motivation, Its Types, and Its Impacts in Language Learning. International Journal of Business and Social Science, 24.

Noels, K. A., Pelletier, L. G., Clement, R., \& Vallerand, R. J. (2000). Why are you learning a second language? Motivational orientations and self-determination theory. Language Learning, 50, 57-85. 
Motivation,

Noels, K. A., Clement, R., \& Pelletier, L. G. (2001). Intrinsic, extrinsic, and integrative orientations of French Canadian learners of English. Canadian Modern Language Review 57, 424-444.

Pintrich, P.L. \& Schunk, D. H. 1996. Motivation in education: Theory, research and applications. Englewood Cliffs, NJ: Prentice Hall Regents.

Rehman, A., Bilal, H. A., Sheikh, A., Bibi, N., \& Nawaz, A. (2014). The Role of Motivation in Learning English Language for Pakistani Learners. International Journal of Humanities and Social Science, 1.

Root, E. (1999). Motivation and Learning Strategies in a Foreign Language Setting: A Look at a Learner of Korean. Department of English as a Second Language: University of Minnesota.

William, M. and burden, R. L. (1997) Psychology for Language Teachers. Cambridge: Cambridge University Press.

Zareian, G. \& Jodaei, H. (2015). Motivation in Second Language Acquisition: A State of the Art Article. International J. Soc. Sci. \& Education, 5. 